OPEN ACCESS

Edited by:

Jingzheng Ren,

Hong Kong Polytechnic University,

Hong Kong

Reviewed by:

Ruojue Lin,

Hong Kong Polytechnic University,

Hong Kong

Xiaoping Jia,

Qingdao University of Science and

Technology, China

${ }^{*}$ Correspondence:

Lu Sun

sun./u@nies.go.jp

Specialty section:

This article was submitted to

Multi-criteria Decision Making,

a section of the journal

Frontiers in Sustainability

Received: 24 December 2020

Accepted: 05 March 2021

Published: 06 April 2021

Citation:

Wang J, Sun L, Fujii M, Li Y, Huang Y, Murakami S, Daigo I, Pan W and Li Z

(2021) Institutional, Technology, and

Policies of End-of-Life Vehicle

Recycling Industry and Its Indication

on the Circular Economy-

Comparative Analysis Between China

and Japan. Front. Sustain. 2:645843.

doi: 10.3389/frsus.2021.645843

\section{Institutional, Technology, and Policies of End-of-Life Vehicle Recycling Industry and Its Indication on the Circular Economy- Comparative Analysis Between China and Japan}

\author{
Jia Wang ${ }^{1}$, Lu Sun ${ }^{2 *}$, Minoru Fujii ${ }^{2}$, Yuke Li ${ }^{1}$, Yonghe Huang ${ }^{1}$, Shinsuke Murakami ${ }^{3}$, \\ Ichiro Daigo ${ }^{4}$, Wei Pan ${ }^{1}$ and Zhenbiao $\mathrm{Li}^{1}$ \\ ${ }^{1}$ Center for Automotive Strategy and Policy Research, China Automotive Technology and Research Center, Tianjin, China, \\ ${ }^{2}$ Center for Social and Environmental Systems Research, National Institute for Environmental Studies, Tsukuba, Japan, \\ ${ }^{3}$ Department of Technology Management for Innovation, School of Engineering, The University of Tokyo, Tokyo, Japan, \\ ${ }^{4}$ Department of Materials Engineering, The University of Tokyo, Tokyo, Japan
}

With economic development and accelerated industrialization, resource consumption has seen rapid increase. Against such a consumer boom, vehicle ownership has rocketed up, which also brings surging numbers of end-of-life vehicles (ELVs). Thus, recycling and disposing those ELVs turn out to be a head-scratching issue. As a result, how to effectively collect, dismantle, and recycling ELVs grows into a global topic. In China, over the past two decades, the Chinese vehicle ownership had grown rapidly to 261.5 million in 2019. Likewise, the ELV recycling industry in China also faces mounting challenges, especially in policy-making, recycling system, and the remanufacturing industry. The key challenges in the sector are the loss of ELVs and illegal dismantling. In recent years, despite the emergency of a group of large-scale quality dismantling enterprises, the overall technological level in the industry and the recycling rate require further advancement. In contrast, countries with highly mature automobile industry have seen a different image. Japan, for instance, has been the pioneer in the field of ELV recycling, created well-rounded laws and regulations on the industry, and developed advanced know-hows to cope with technical challenges. Therefore, this study, firstly, tries to summarize the laws and regulations and the latest industrial status of ELVs recycling in China and Japan. The deviation, if any, shall be analyzed between Japan's existing system and policy design, and the possible causes. Secondly, the Material Flow Analysis (MFA) method is adopted to analyse the changes of Resource Input Intensity (RII) of steel and oil for vehicles over the past 10 years, which shall provide the basis for future research on material recycling and waste treatment. Thirdly, the overall recycling rate of China's automobile products is analyzed, with the prediction that as technologies advance and related policies evolve, the recycling rate shall increase from 90 to $98 \%$ within 5 years. Fourthly, against the backdrop of circular economy development, this 
paper tries to provide an enlightenment to ELVs recycling management in China and Asian countries, with the stage of social development, policy system, social awareness of resource recycling, market guidance and other factors combined in the research. As a whole, this study tries to facilitate the sustainable development of the ELV recycling industry, provides support for the policy-making, and contributes to the building of a resource-saving and recycling-oriented society.

Keywords: China and Japan, ELVs, recycling, institutional, technology, policy

\section{INTRODUCTION}

Thanks to the advancement of the automobile industry and the upsurge of vehicle ownership, End-of-life Vehicles (ELVs) has surged accordingly (Kanari et al., 2003; Soo et al., 2021). Through years of development, the EU, Japan, the United States, and other major automobile manufactures and consumers have fully acknowledged the importance of ELVs disposal (Daniels et al., 2004). Fortunately, stakeholders have been on the right track to move forward recycling work, and a relatively solid recycling industry have been emerged after years of efforts (Sakai S. I. et al., 2007; Jody and Daniels, 2011). As for China, in 2019, automobile ownership reached 254 million, equivalent to that in the United States. However, the recycling industry has failed to keep up with the development of the automobile manufacturing. On top of it, some issues go with the policymaking, regulations, and recycling, among other aspects. Existed study have summarized China's legal requirements for ELVs recycling and analyzed such issue as the loss of ELVs in China, the research has proposed that about $2 / 3$ of them have entered into illegal markets ( $\mathrm{Li}$ et al., 2014). Some research focus on analyzing the driving force of ELVs recycling business with the help of ISM (Zhou et al., 2019), evaluating the efficiency and sustainability of ELV recycling enterprises (Pan and Li, 2016), and assuming the prediction of the future of China's ELV industry (Li Y. et al., 2020); Researchers also have taken the legislative systems governing ELV recycling and the extended producer responsibility (EPR) in developed countries for reference (Wang and Chen, 2013), demonstrated their prediction over China's future material recycling and carbon emissions through dynamic materials flow analysis and life cycle assessment (Liu M. Z. et al., 2020), delved into the recycling system of the used auto parts for remanufacturing in China based on the EPR system (Wang and Chen, 2011), and carried out identification analysis of the environmental impact of varied levels of ELVs recycling technologies through LCA method (Li et al., 2016). Currently, the main challenges confronting China's ELV recycling industry are massive loss of ELVs and insufficient recycling of materials. As a result, future research shall focus on how to establish an effective mechanism from the perspectives of policy-making and institution-establishing to guide the ELVs industry into regular operation, as well as how to improve the overall recycling rate of materials.

Due to an early start in the automobile industry and continuous promotion of circular development, Japan has seen a relatively mature ELV recycling system. In Japan's recycling system, automobile manufacturers have played an indispensable role, and EPR has been well-implemented. Japan's End-of-Life Vehicle Recycling Act (MOEJ) stipulates that manufacturers shall be obliged to receive or deal with the airbags, fluorocarbons and ASRs from the ELVs they sell. Some studies have summarized the establishment of Japan's recycling system and the performing recycling technologies in China and Japan (Zhao and Chen, 2019), drawn a comparison of the ELV recycling methods, scopes and industrial scales between China and Japan, and pointed out such issues as non-standard recycling processes, and risks of potential environmental pollution in China (Hu et al., 2009), and evaluated the benefits of Japan's ELV recycling and dismantling operations through $\mathrm{CO}_{2}$ emission reduction (Kenta Sato et al., 2019). There are some studies have compared the regulations on the ELV recycling management, dismantling technologies, etc. between China, Japan, and South Korea (Che et al., 2011), investigated ASR disposal technologies in the ELV recycling process (Sakai S. I. et al., 2007), investigated the process in practice of dismantling and utilizing parts and materials in ELVs sectors (Daisaku et al., 2003; Tomohiro et al., 2004), and analyzed the impact of Japan's End-of-Life Vehicle Recycling Act (MOEJ) on the industry (Ogushi and Kandlika, 2005). All in all, Japan has formed a relatively well-round legal system, which guides the owners to deliver their vehicles with recycling fees. On top of that, Japan has formulated the ASR recycling target to guide the improvement of the vehicle recycling rate. With the market-oriented development of the industry, Japan has been confronted with the challenge of balancing policy designs and market demands.

In Asia, most developing countries, including China, have been confronted with the issue that the development of automobile recycling has lagged behind the manufacturing, circulation, and other segments in the industrial chain. The recycling of ELVs has simply not received enough attention, resulting in the loss of ELVs and low levels of recycling technologies. The past studies have mainly focused on comparing laws and regulations, systematic management, and technologies between various markets, while they have demonstrated limited researches on social awareness or adoption of quantitative analysis methodology. What's more, there is no research on the changes of Japan's recycling system, or on whether it could meet the emerging needs of the industry. To fill in the aforementioned research gaps, this study adopts a comparative analysis of the ELVs recycling industry between China and Japan. It aims to comprehensively examine the challenges and directions of ELVs recycling at varied development stages, from the perspective of 
the recycling system, policy-making, market evolvement, and material flow. This paper quantitatively analyses the material flow and resource cycle of ELVs recycling in China. With the analysis, it tries to help to manage ELVs recycling more efficiently, promote the recycling of materials, and contributes to the development of circular society. As a result, this paper conducts a study of the following four aspects in China, Japan, and other Asian countries, the status of materials recycling of ELVs, the impact of social awareness of resource recycling on the industry's development, the issues in the recycling system which is incompatible with the industry's development, and the discussions and suggestions on the balanced relationship between the policy systems and the industry's development.

\section{COMPARATIVE ANALYSIS ON THE SCALE OF THE ELVs COLLECTING AND DISMANTLING INDUSTRY}

ELVs in China have demonstrated a continuous upward trend from 2010 to 2019 (Figure 1). In 2019, the number was 2.295 million, generating an annual growth of $15.3 \%$, of which 1.951 million were automobiles, an increase of $16.8 \%$ over the previous year $\left(2020^{1}\right)$. As for the automobile ownership, there were 250 million in $2019^{2}$, and the proportion of ELVs to the ownership was about $0.77 \%$. As for the market players, there were 755 ELVs collecting and dismantling enterprises and 2,271 collecting branches in China by the end of 2019 (2020).

In contrast, ELVs quantity in Japan has been relatively stable over the years, with an average of 3.4 million per year (Figure 1). In 2019, there were 3.36 million ELVs in Japan, and the proportion of ELVs to the ownership was about $4.3 \%$. In fact, some ELVs have been disposed of carelessly in Japan too, yet the number has been relatively small. As for the market players, according to the statistics published by the Japan Automobile Recycling Promotion Center (JARC), there were 13,606 ELVs collectors, 3,468 fluorocarbons collectors, 3,367 ELVs dismantling enterprises, and 913 shredding companies by the end of 2019. And the recycling rate of ASR reached 98.1\%, which should exceed $99 \%$ when converted into vehicle recycling rate (Automotive Recycling Data Report, 2019³).

When China and Japan are compared, it could be seen that the number of ELVs in Japan is relatively stable, while that of China demonstrates a continuous growing trend. By the end of 2019, the ELVs number of Japan is twice that of China. In terms of the proportion of ELVs number to the ownership, China has always seen a low number, $<1 \%$ over the years, while that in Japan has been relatively high, standing at about $4.4 \%$.

\section{RECYCLING OF ELVs MATERIALS}

\section{China}

As an effective analysis tool, Materials Flow Analysis (MFA) could help to master the input and output of industrial materials

\footnotetext{
${ }^{1}$ Data of Scrapped Motor Vehicles. Ministry of Commerce of China, 2009-2019.

${ }^{2}$ Data of Automobile Ownership. China Bureau of Statistics, 2009-2019.

${ }^{3}$ Japanese Automobile Industry. Tokyo: Japan Automobile Industry Association, 2018-2019.
}

and waste generation to effectively supervise the direction of material flow and the amount between the economic systems and the ecological environment, thus reducing resource input, improving resource efficiency and reducing waste discharge. With the help of MFA, the materials' purchase, consumption and circulation in the automobile industry could be identified, which shall provide scientific basis for promoting ELV recycling. In particular, three key indicators: direct material input (DMI), system processing output (SPO), and resource input intensity (RII), are selected for material flow analysis. SPO shows the pollutants from the system, and the wastes that have not been reused in it, while RII measures the quality of material consumed per unit automobile in the system, which equals to the amount of resource input divided by the automobile production value (EUROSTAT, 1997, 2001; Bao, 2011).

This paper delves into the statistics of material flow system of China's automobile industry from 2010 to 2019. As shown in Table 1, the automobile ownership, at the beginning of 2019, was 240.28 million, while, at the end of that year, the number was 261.50 million, with 25.72 million units manufactured, and 25.77 million sold; the material input (steel) or consumption at the manufacturing stage was about 50 million tons; the ELVs collected were about 5.85 million units, while the waste steel, nonferrous metals, plastics, and rubber produced added to about 15 million tons.

The result of material flow analysis of China's automobile industry is shown in Figure 2. In the production stage, iron, and steel are the direct material input for automobile production, which stood at 50 million tons in 2019. The input manufactured 25.72 million units of automobiles and generated 78.60 million tons of solid waste. At the consumption stage, Chinese had driven 261.5 million units of automobiles and consumed 222.3 million tons of gasoline, diesel, and lubricating oil, and generated 16.04 million tons of air pollutants. At the scrape stage, there was 5.85 million vehicles sent to receive scrape treatment, which generated 15 million tons of scrap steel, non-ferrous metals, plastics, and rubbers. In short, the SPO of automobile industry in China was 109.6 million tons in 2019.

The changes in resource consumed in the industry could be seen clearly from the Resource Input Intensity (RII).

$$
\begin{array}{r}
\mathrm{RII}_{\text {steel }}=\text { Material input (steel)/Automobile production } \\
\mathrm{RII}_{\mathrm{oil}}=\text { Material input (oil)/Automobile ownership }
\end{array}
$$

Figure 3 shows that the steel input per vehicle has been decreasing over the years, which has been consistent with the lightweight development trend of vehicles in China. The main recyclable materials at the scrap stage in China are steel. The reduction of steel affects the recycling rate of vehicles to some extent. The reduction of oil resource input intensity per vehicle from Figure 3 is mainly due to the continuous improvement of China's vehicle fuel consumption standards in recent years and the use of new energy vehicles. It can be seen that the extensive use of new energy vehicles will have a greater impact on China's resource consumption structure in the future. The same 


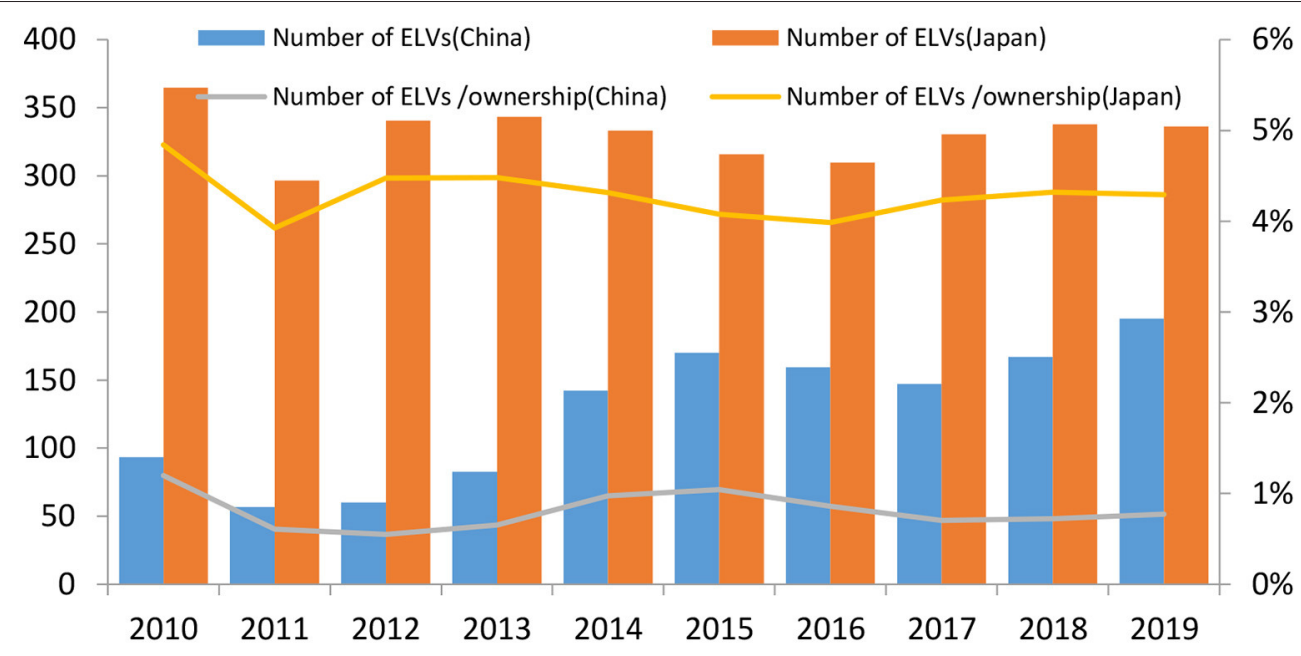

FIGURE 1 | Comparison of ELV recycling scale in China and Japan (Unit: 10,000 vehicles).

TABLE 1 | Material flow system data of China' automobile industry (2010-2019).

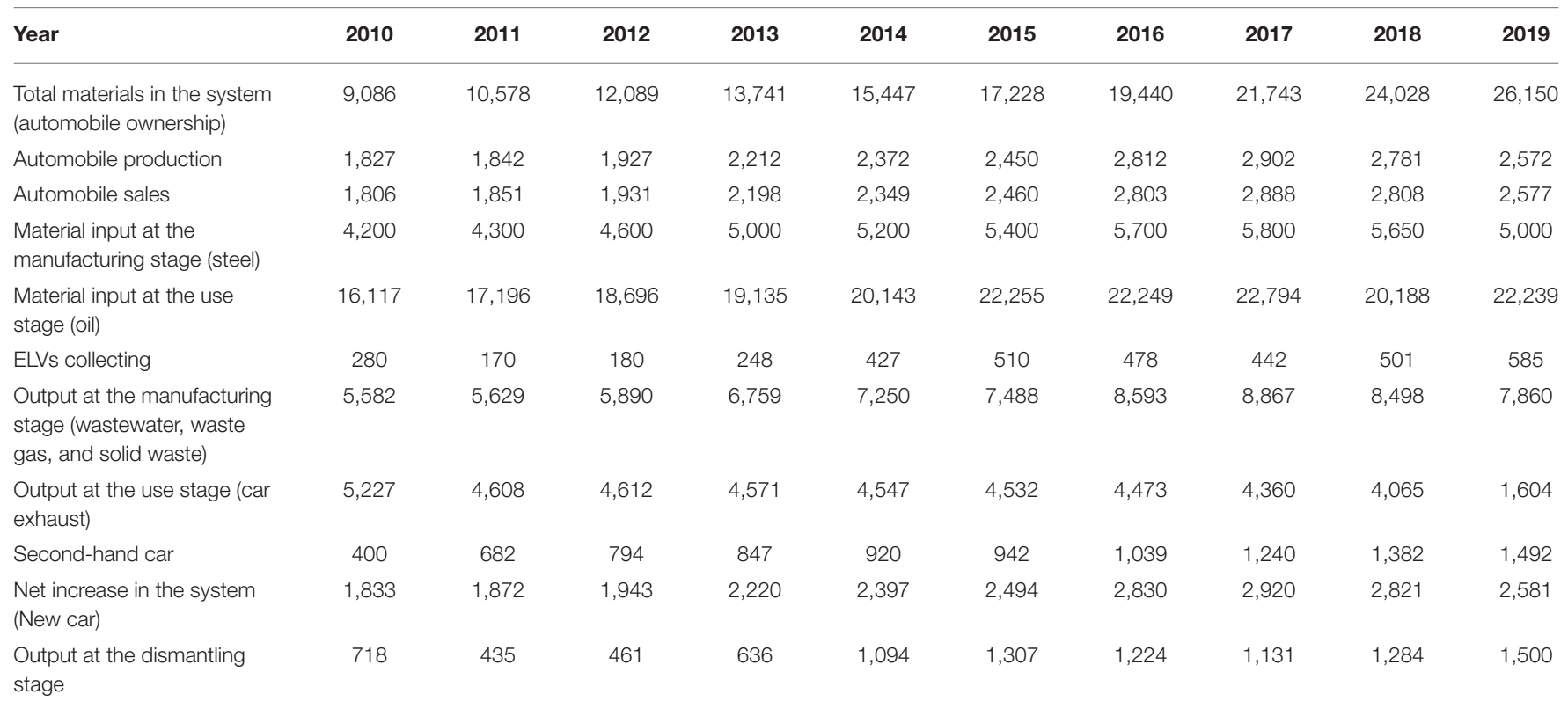

Unit: 10,000 vehicles, 10,000 tons.

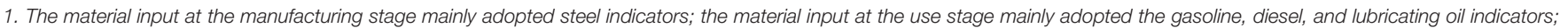

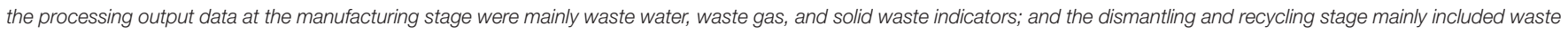
steel, non-ferrous metal, plastics, and rubber indicators.

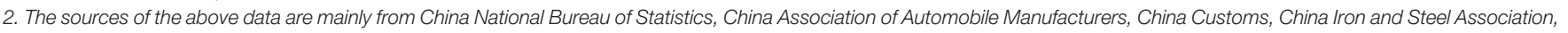
corporate environmental assessment reports and survey data of China Automotive Technology and Research Center.

3. The ELVs collecting data includes the ELVs entering authorized enterprises and the lost ELVs.

conclusion can be drawn from the data of new energy vehicles in Figure $4^{4,5}$.

As could be seen in Figure 5, this paper studies the ways of recycling of ELV parts and materials in China. Currently,

\footnotetext{
${ }^{4}$ The Ownership and Sales of New Energy Vehicles in China. Ministry of Public Security, 2014-2019.

${ }^{5}$ The Ownership and Sales of New Energy Vehicles in China. CATARC, 2009-2013.
}

the recycling rate of ELVs stands at around 90\% (Shen, 2013; $\mathrm{Ni}, 2015$; Chen, 2016). Although the proportion of steel in an automobile shall further drop in the future, this paper assumes that the recycling rate shall grow. With a series of policies enacted in China, the application of remanufacturing products shall be on the rise, and the reuse rate of parts shall be considerably increased. Meanwhile, with the improvement of material recycling technologies and wide adoption of ASR 


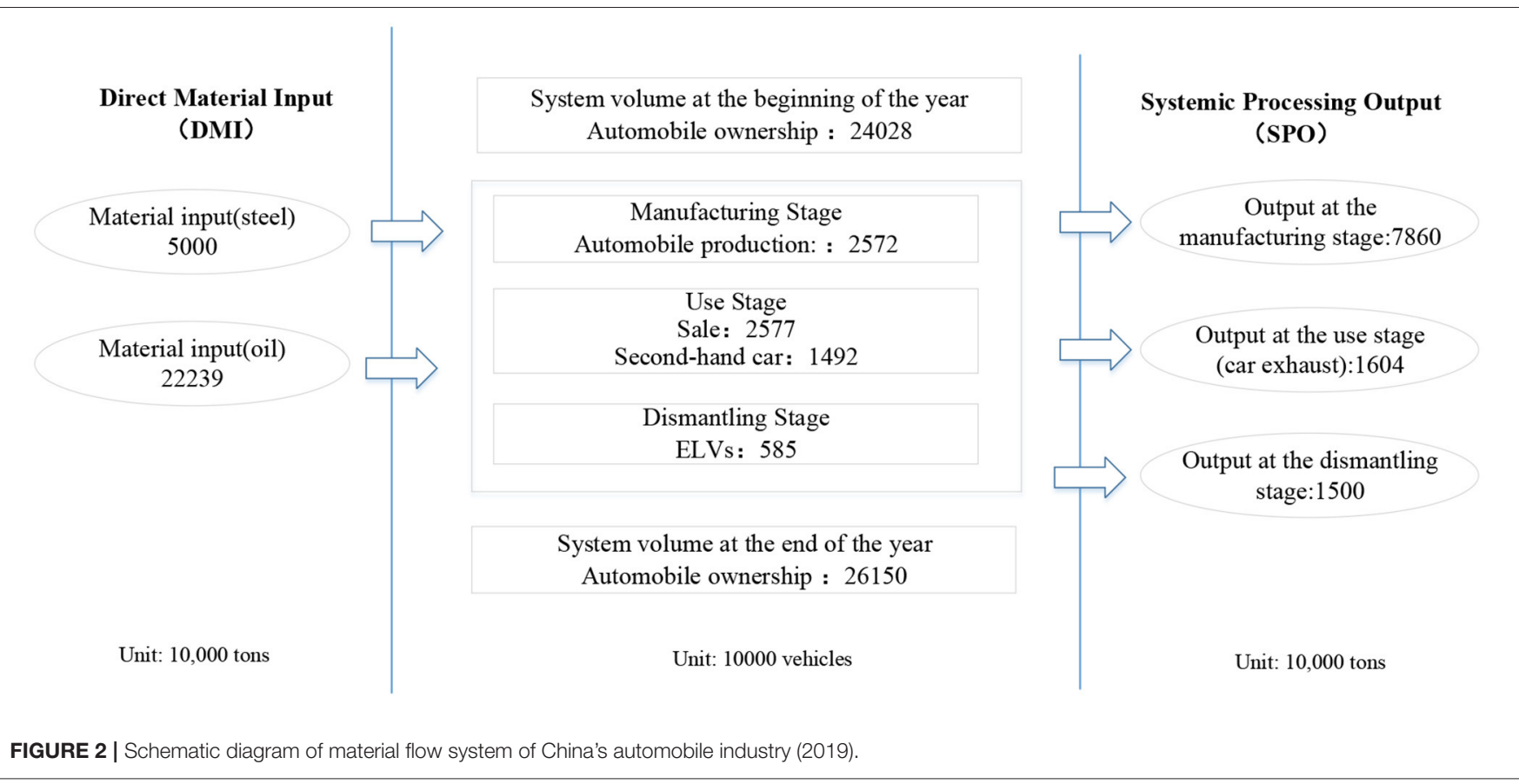

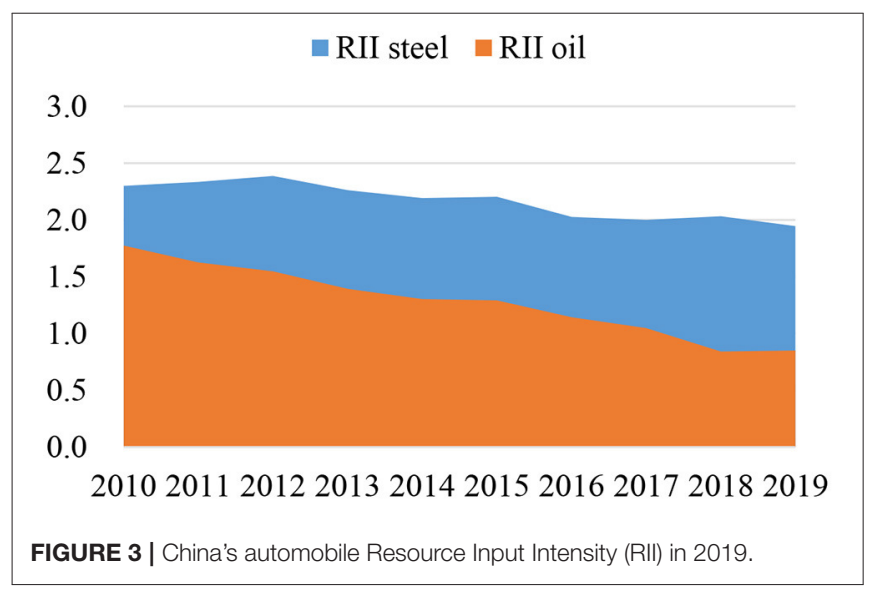

recovery energy application, it is expected that the recycling rate shall reach up to $98 \%(\mathrm{Ni}, 2015$; Chen, 2016).

In terms of the recycling of products, remanufacturing is on the rise. Remanufacturing is an advanced form of recycling, which could make crucial contribution to energy conservation. Taking engines as an example, when compared with the manufacturing of a new one, remanufacturing an old one could save $80 \%$ of energy, $88 \%$ of water, and $92 \%$ of chemicals while reducing $70 \%$ of waste (Ellen MacArthur Foundation, 2013). When the life cycle of engines is viewed, the average global warming potential (GWP) created from making a new engine equals 0.7 tons of $\mathrm{CO}_{2}$ (Bobba et al., 2020). However, remanufacturing an old one, depending on the variance of amount of remanufactured parts to replace unused ones, could reduce GWP by $66.4-77.9 \%$, which plays an undeniable role in environmental protection (Bobba et al., 2020). The GWP impact analysis refers to the international life cycle data system (International Reference Life Cycle Data System, 2010). The basic scenario is set as the GWP impact of a new engine (average weight $245 \mathrm{~kg}$ ) produced during the life cycle (Ardente et al., 2018).

Although it was prohibited by regulations before 2019 to remanufacture the engines of ELVs, there existed illegal dismantling of ELVs, and some of the engines were remanufactured. As presented in Table 1, an estimation of the proportion has been made of remanufactured engines in ELVs under two scenarios.

(1) The minimum proportion scenario: the proportion of remanufactured engines in ELVs is $1 \%$

(2) The maximum proportion scenario: the proportion of remanufactured engines in ELVs is 3\%.

The number of remanufactured engines in different scenarios has been calculated (Table 2). The GWP difference is comparted between the same amount of remanufactured and newly produced engines according to the maximum GWP reduction (77.9\%) (Figure 6). In 2019, under the max scenario, GWP difference will reach 97,000 tons of $\mathrm{CO}_{2} \mathrm{eq}$, which is of great significance to the environment protection.

\section{Japan}

In Japan, improving the recycling rate of ASR has been the goal behind related laws and regulations, which stipulate that the recycling rate should reach $30 \%$ in $2005,50 \%$ in 2010 , and $70 \%$ in 2015 (Ni, 2015). To make it happen, automobile manufacturers are held accountable for the recycling of ASR and the final disposal of airbags, fluorocarbons, and wastes, while the disposal costs come from the recycling fees paid by the vehicle users. 


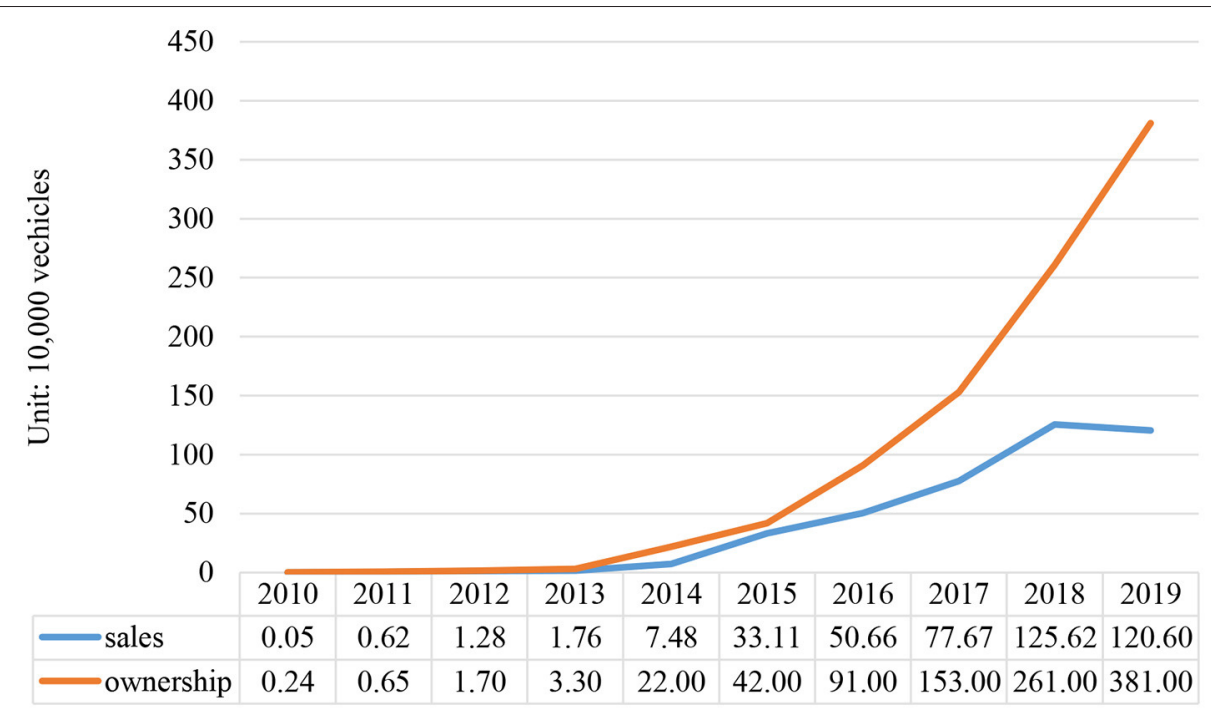

FIGURE 4 | The ownership and sales of new energy vehicles in China (2010-2019).

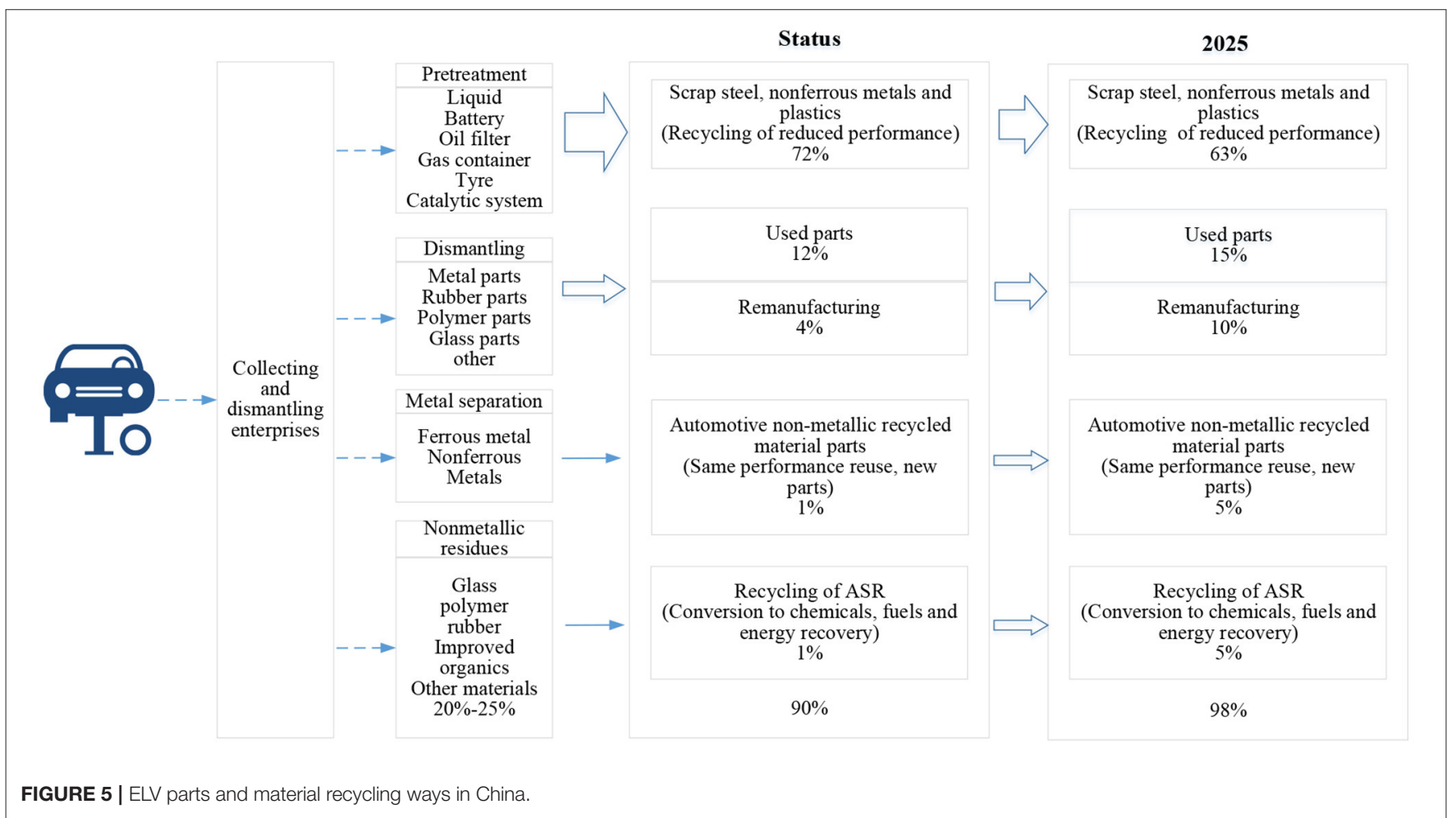

With difficulties of data collection and other issues taken into consideration, this paper does not research on Japan's overall material flow in the industry, but carries out MFA on the recycling stage (Figure 7). According to statistics from JARC, Japan's ASR recycling rate hit $98.1 \%$ in 2018 , and the overall recycling rate exceeded $99 \%$ (Automotive Recycling Data Report, 2019).

\section{ELV RECYCLING POLICIES AND MANAGEMENT SYSTEM \\ Policies \\ China}

Among the sectors in the secondary industry, ELV recycling plays a crucial role in the building of a circular society. 
TABLE 2 | Number of remanufactured engines in different scenarios.

\begin{tabular}{|c|c|c|c|c|c|c|c|c|c|c|}
\hline Year & 2010 & 2011 & 2012 & 2013 & 2014 & 2015 & 2016 & 2017 & 2018 & 2019 \\
\hline Scenario 1 (min) & 2.8 & 1.7 & 1.8 & 2.48 & 4.27 & 5.1 & 4.78 & 4.42 & 5.01 & 5.85 \\
\hline Scenario 2 (max) & 8.4 & 5.1 & 5.4 & 7.44 & 12.81 & 15.3 & 14.34 & 13.26 & 15.03 & 17.55 \\
\hline
\end{tabular}

Unit: 10,000 .

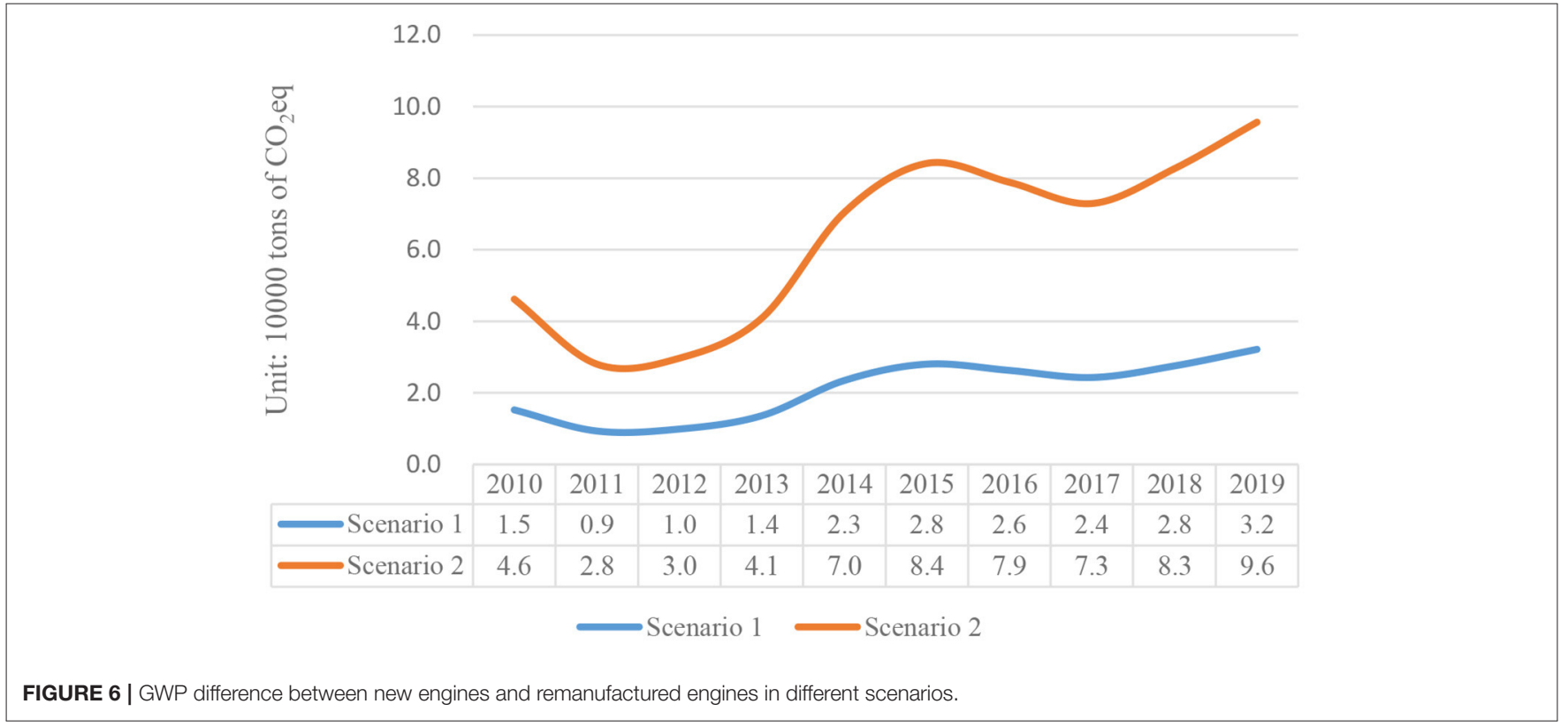

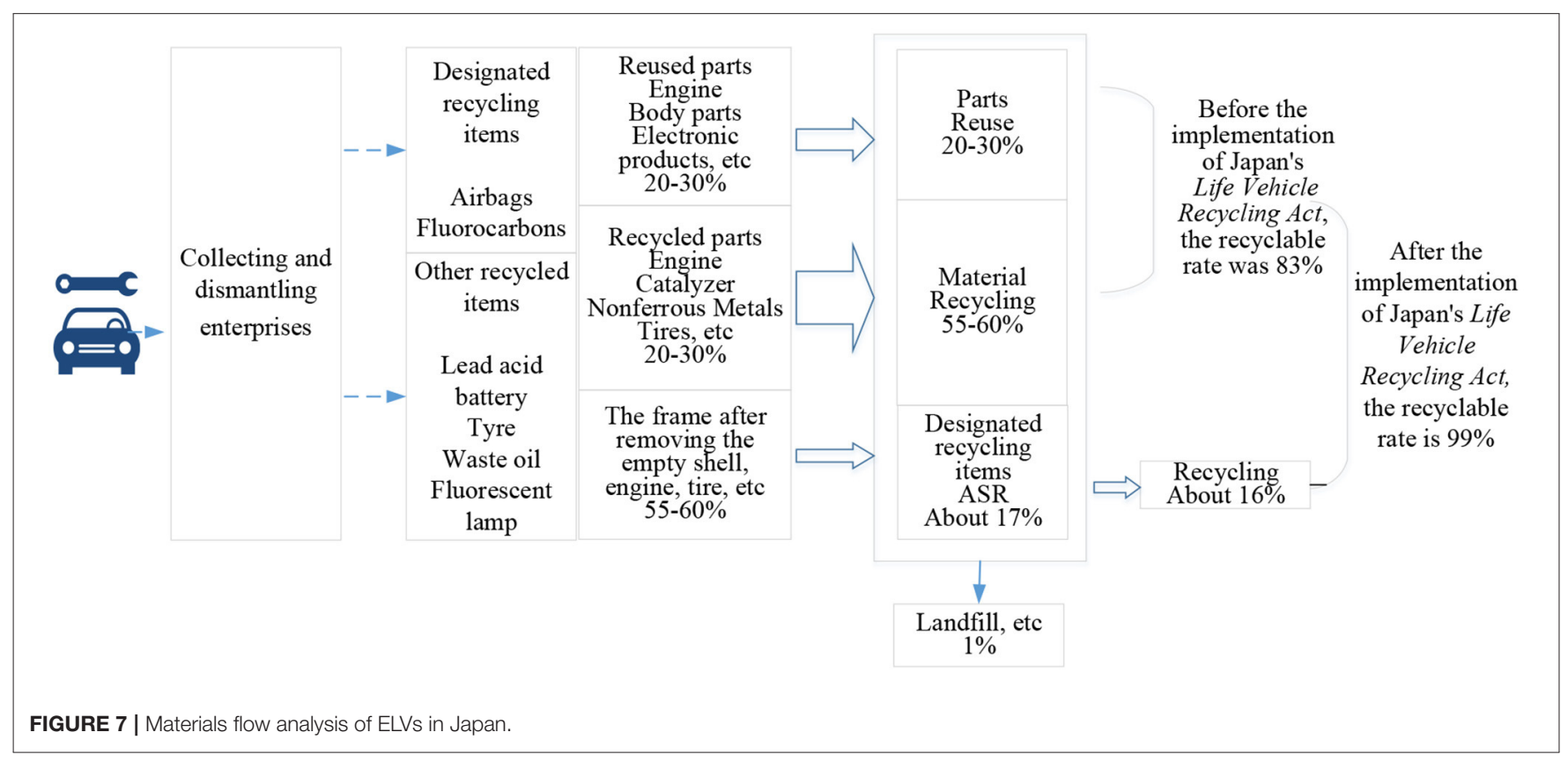

According to the definition in the Circular Economy Promotion Law of the People's Republic of China, circular economy refers to "the general term for the reduction, reuse, and recycling activities in the process of production, circulation, and consumption, etc." (The National People's Congress of China, 2008). ELV recycling activities concern issues such as safety, environment protection, and resource utilization. According to the field attribute of the ELVs recycling industry, 
TABLE 3 | China's circular economy policies and regulations systems.

\begin{tabular}{|c|c|c|}
\hline Issue year & Policy name & Issue department \\
\hline 1995 (revised in 2020) & $\begin{array}{l}\text { Law of the People's Republic of China on the Prevention and Control of } \\
\text { Environmental Pollution by Solid Waste }\end{array}$ & National People's Congress \\
\hline 2007 & Comprehensive Working Plan for Energy Conservation and Emission Reduction & $\begin{array}{l}\text { National Development and Reform } \\
\text { Commission, etc. }\end{array}$ \\
\hline 2008 & Circular Economy Promotion Law of the People's Republic of China & National People's Congress \\
\hline 2010 & $\begin{array}{l}\text { Decision on Accelerating the Cultivation and Development of Strategic Emerging } \\
\text { Industries }\end{array}$ & State Council \\
\hline 2013 & Directory of Key Products and Services in Strategic Emerging Industries & $\begin{array}{l}\text { National Development and Reform } \\
\text { Commission }\end{array}$ \\
\hline 2015 & Opinions on Accelerating the Ecological Civilization Construction & State Council \\
\hline 2017 & Implementation Plan of Extended Producer Responsibility System & State Council \\
\hline 2017 & Circular Development Leading Plan & $\begin{array}{l}\text { National Development and Reform } \\
\text { Commission }\end{array}$ \\
\hline
\end{tabular}

the main policies governing circular economy could be seen in Table 3.

Since the beginning of the twenty-first century, China has seen rapid development in the automobile industry and continuous increase of ELVs, alongside the occurrences of illegal assembly of vehicles and other illegal activities. To supervise ELV recycling sector, the State Council of the People's Republic of China issued the Measures for Administration of Recycling of End-of-life Vehicles in 2001 (State Council of China, 2000), promote the ELV recycling industry to operate legally. The measures have served as the main legal ground for the development of the industry currently, and for the introduction of subsequent policies. Nowadays, most ELV collecting and dismantling enterprises in China are of small size with relatively outdated technologies. Yet, the sector has imposed mounting pressure on environmental protection. To better protect the environment and advocate energy saving and emission reduction, the Chinese government have passed a succession of policies, such as Technical Policy on Recycling of Automotive Products (National Development Reform Commission of China, 2006), Technical Specifications for End-oflife Vehicles Collecting and Dismantling Enterprises ${ }^{6,7}$, and other technical policies and standards, which have advanced the ELV recycling industry in China (Table 4).

\section{Japan}

Japan's management on the automobile recycling industry have focused on waste disposal and recycling. The main higher-level laws governing waste disposal are the Waste Disposal Law (1970) and the Fluorocarbons Recovery and Destruction Law (2002). The legal basis for recycling is established on the Resource Recycling Promotion Law (1991) and the Basic Law for Establishing the Recycling-based Society (2000). The Resource Recycling Promotion Law enacted in 1991 (revised in 2000 as the Law for the Promotion of Effective Utilization of Resources) introduced the concept of

${ }^{6}$ GB 22128-2008. Technical Specifications for End-of-Life Vehicles Recycling and Dismantling Enterprise.

${ }^{7}$ GB 22128-2019. Technical Specifications for End-of-Life Vehicles Collecting and Dismantling Enterprise. resource recycling into law for the first time, establishing the " $3 \mathrm{R}$ ” policy, i.e., Reduce, Reuse, and Recycle (Aki, 2016).

On top of the aforementioned laws and regulations, Japan has implemented such laws as Waste Disposal Law, Fluorocarbons Recovery and Destruction Law, and Law for the Promotion of Effective Utilization of Resources, regarding the automobile industry. However, it is the End-of-Life Vehicle Recycling Act (MOEJ) (2002) that makes all the difference (Ministry of Economy, 2002) which was officially put into effect on January 1,2005 . The law is the one that was specifically enacted for automobile scrapping and recycling the disposals. After End-ofLife Vehicle Recycling Act (MOEJ) has been put into effect, a new ELV recycling system have been established, bringing Japan's automobile collecting, dismantling and recycling industry into a new development stage.

\section{The Management System of ELV Recycling Overall Framework \\ China}

The ELV recycling sector in China has been dominated by enterprises undertaking ELVs collecting and dismantling business, while vehicle manufacturers have not involved in it yet (Wang et al., 2015). To make things worse, there has lacked professional shredding firms (Figure 8). When the value chain of ELV treatment is viewed, ELVs, firstly, shall be sent by end owners to dismantlers. Then the collected automobiles are dismantled, in which useful parts are sold, and car bodies cut as per requirement by steelmakers, which eventually end up in steelmakers' workshops as scraps (State Council of China, 2000).

\section{Japan}

As for the legal framework in Japan, it could be seen from the following event. In July 2002, the Japanese government passed the End-of-Life Vehicle Recycling Act (MOEJ), which took effect on January 1, 2005. The law stipulates that recycling fees be paid, and an electronic trace and feedback system be introduced that covers the entire process. The law has successfully bound stakeholders into an interlink, such as vehicle owners, automobile manufacturers, ELVs collectors, and dismantling 
TABLE 4 | China's policies and regulations on ELV recycling industry.

\begin{tabular}{ll}
\hline Issue year & Policy name \\
\hline 2001 (revised in 2019) & Measures for Administration of Recycling of End-of-life Vehicles \\
2008 (2019 revised edition) & $\begin{array}{l}\text { Technical Specifications for End-of-life Vehicles Collecting and Dismantling } \\
\text { Enterprises (GB22128) }\end{array}$ \\
2012 & Regulations for Compulsory Scrapping Standard of Motor Vehicles \\
2020 & Detailed Rules for the Implementation of the Measures for Administration \\
& of Recycling of End-of-life Vehicles
\end{tabular}

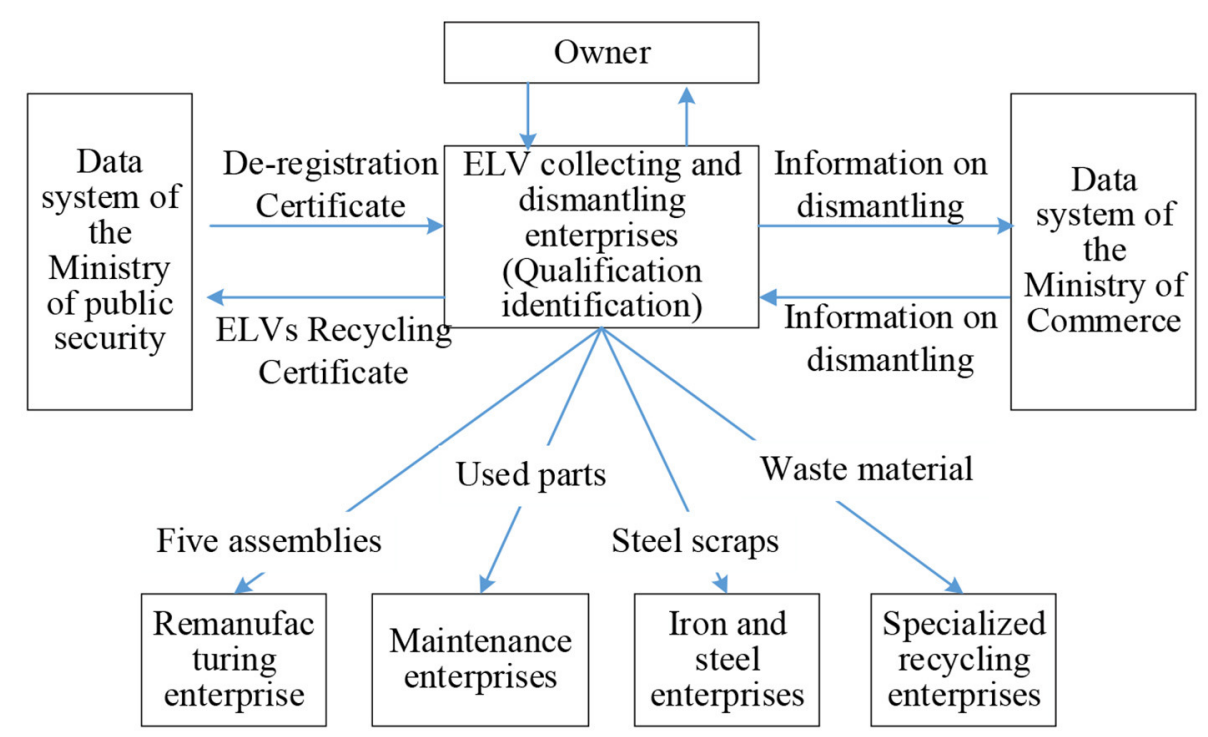

FIGURE 8 | China's ELV recycling management framework.

firms, fluorocarbons recycling enterprises, resource recycling companies, and industry associations. Hence, an ELV recycling system has taken form (Figure 9).

The End-of-Life Vehicle Recycling Act (MOEJ) specifies that users should bear the disposal cost of fluorocarbons, airbag, and automobile shredder residue (ASR) items from ELVs. As a result, owners of disposed automobiles shall pay recycling fees when they purchase new cars. The sum and data shall be managed by JARC and Japan Auto Recycling Partnership (JARP), which shall provide necessary assistance in the disposal of waste products, such as fluorocarbons and airbags. Varied requirements have been established of three substances: ASR, fluorocarbons and airbags in Japan's automobile recycling system. Based on such a system, three circulation routes have been formulated for ELVs, information, and capital in the recycling process, which jointly constitute the ELVs recycling system in Japan (Ministry of Economy, 2002; Japan's Ministry of Economy, 2005).

\section{Responsible Subject}

The participants and responsibility-taking of the ELV recycling system in China and Japan are varied (Figure 10). In Japan, diversified entities participate in it, including ELVs collectors, dismantlers, fluorocarbons collectors, shredders, and automobile manufacturers/importers. In contrast, the recycling system in
China, however, the ELV dismantlers play a key role, which undertake the collection of all ELV, dismantling, and part of shredding, among other works.

As a matter of fact, Japan's recycling system has been designed under the guidance of Extended Producer Responsibility (EPR), in which consumers must pay the disposal fees of vehicles, and are obliged to hand their ELVs over to appropriate collectors, while automotive manufacturers shall appropriately manage the aforementioned three kinds of wastes. In contrast, Chinese consumers are not obligated to pay recycling fees. According to the current law (Measures for Administration of Recycling of Endof-life Vehicles), collecting and dismantling enterprises shall pay ELV owners at market prices. To make things worse, automobile manufacturers have failed to play a crucial role in the system (Ministry of Economy, 2002; Japan's Ministry of Economy, 2005).

\section{Regulatory System}

Compared with Japan, China has more regulatory bodies for ELV recycling (Table 5). The Ministry of Commerce has been the administrative authority in charge of the industry, responsible mainly for the certifying of related enterprises' qualification. The agency shall review those enterprises that have filed the application for developing ELV collecting and dismantling business. Those who pass the review shall be granted 


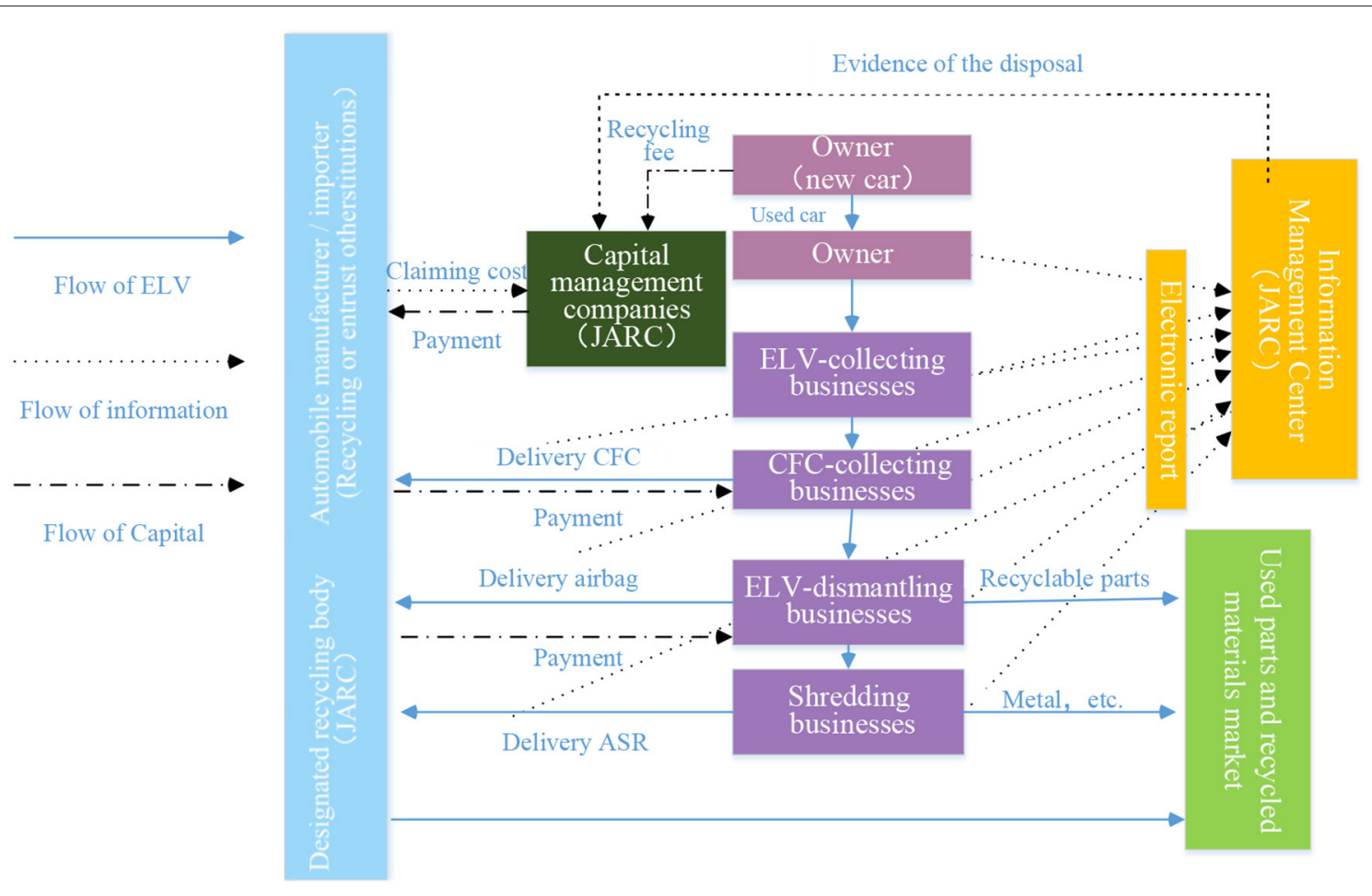

FIGURE 9 | Japan's ELV recycling management framework 0.

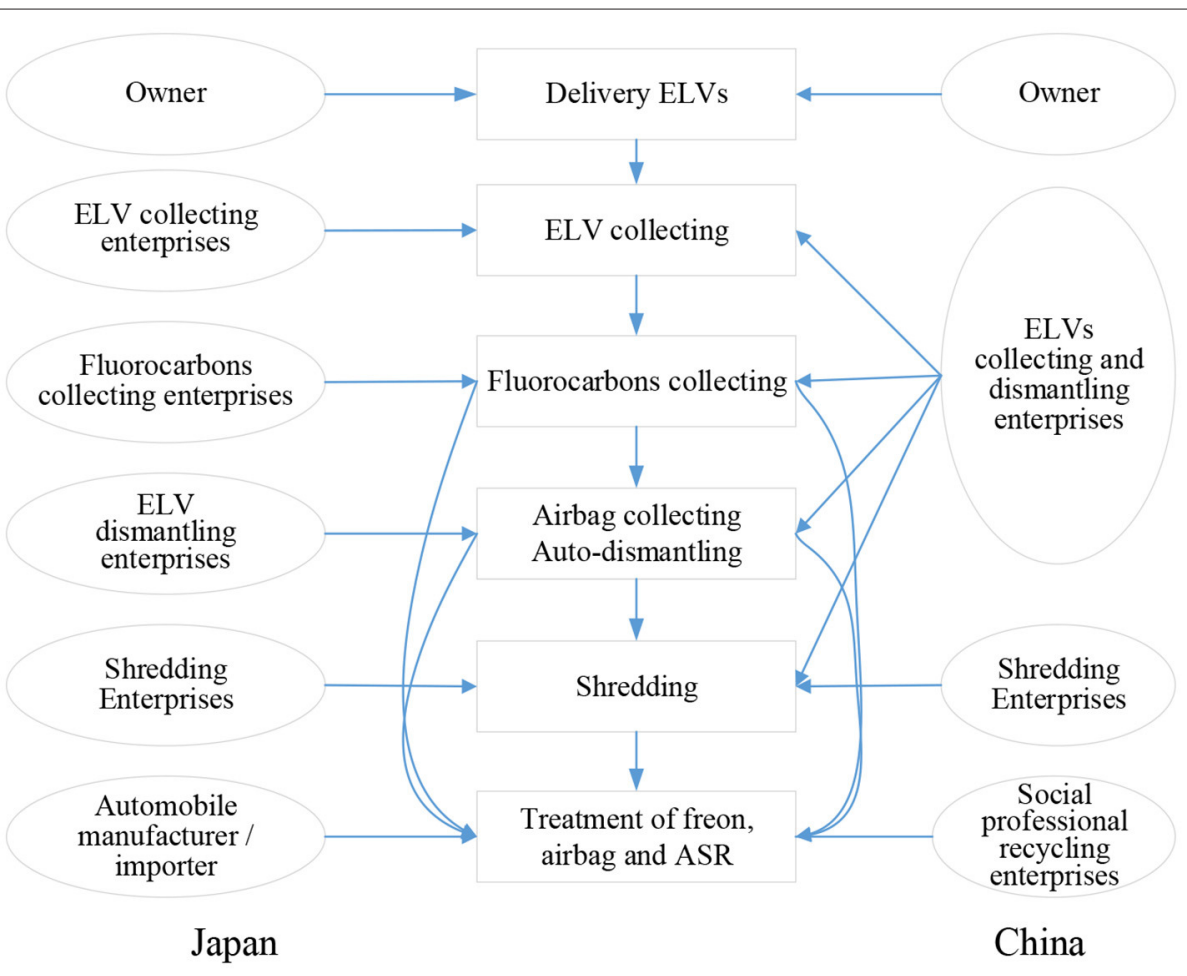

FIGURE 10 | Comparison of participating subjects and responsibilities of the ELV recycling system in China and Japan. 
TABLE 5 | Comparison of the regulatory system of ELV recycling industry in China and Japan.

\begin{tabular}{|c|c|c|c|c|}
\hline \multirow[t]{2}{*}{ Regulation link } & \multicolumn{2}{|r|}{ China } & \multicolumn{2}{|c|}{ Japan } \\
\hline & $\begin{array}{l}\text { Management } \\
\text { department }\end{array}$ & Duties & Management department & Duties \\
\hline \multirow[t]{2}{*}{$\begin{array}{l}\text { Enterprise qualification } \\
\text { certification }\end{array}$} & Commerce department & $\begin{array}{l}\text { Formulate standards, review enterprises' } \\
\text { applications and be responsible for the } \\
\text { issuance of Qualification Certificate }\end{array}$ & $\begin{array}{l}\text { Ministry of Economy, Trade } \\
\text { and Industry and Ministry of } \\
\text { the Environment }\end{array}$ & $\begin{array}{l}\text { Formulate the access and } \\
\text { management standards }\end{array}$ \\
\hline & $\begin{array}{l}\text { Industrial and } \\
\text { commercial } \\
\text { administrative } \\
\text { department }\end{array}$ & $\begin{array}{l}\text { Handle registration procedures and issue } \\
\text { business licenses }\end{array}$ & Local governments & $\begin{array}{l}\text { Register and access approval } \\
\text { for enterprises }\end{array}$ \\
\hline \multirow[t]{3}{*}{ Automobile collecting } & Public security organ & $\begin{array}{l}\text { Issue the De-registration Certificate to } \\
\text { organizations or individuals of ELVs }\end{array}$ & JARC and JARP & $\begin{array}{l}\text { Carry out information and } \\
\text { capital management; } \\
\text { Assist manufacturers or } \\
\text { importers in waste disposal }\end{array}$ \\
\hline & Commerce department & $\begin{array}{l}\text { Uniform formulation and issuance of ELV } \\
\text { recycling Certificate }\end{array}$ & & \\
\hline & $\begin{array}{l}\text { Industrial and } \\
\text { commercial } \\
\text { administrative } \\
\text { department }\end{array}$ & $\begin{array}{l}\text { Supervise the business activities of ELV } \\
\text { collecting enterprises }\end{array}$ & & \\
\hline \multirow[t]{3}{*}{ Automobile dismantling } & Public security organ & $\begin{array}{l}\text { Supervise the public security of } \\
\text { enterprises and the destruction during the } \\
\text { automobile dismantling }\end{array}$ & & \\
\hline & $\begin{array}{l}\text { Industrial and } \\
\text { commercial } \\
\text { administrative } \\
\text { department }\end{array}$ & $\begin{array}{l}\text { Supervise the business activities of } \\
\text { enterprises }\end{array}$ & & \\
\hline & $\begin{array}{l}\text { Environmental } \\
\text { protection department }\end{array}$ & Mainly supervise environmental violations & & \\
\hline
\end{tabular}

the Qualification Certificate. Otherwise, they are forbidden to carry out related businesses. At the same time, administrative agencies relating to industry and commerce, public security and environmental protection shall carry out regulatory supervisions over corresponding process.

Likewise, registration or authority's approval is required to engage in businesses relating to automobile recycling in Japan. Those enterprises, engaged in ELV collection and fluorocarbons recycling, shall register at local governments and be reviewed every 5 years. As for the enterprises who involve in ELV dismantling and shredding shall report to local governments for approval and renewal every 5 years. The approval and renewal standards, on the other hand, are formulated by two central ministries, namely, the Ministry of Economy, Trade and Industry and Ministry of the Environment, and are implemented by governments at all levels as reference (Business Office of the Chinese Embassy in Japan, 2005).

\section{Changes in the Industry's Adaptability of Policies and Management Systems China}

Current policy-making and management system in the ELV recycling sector in China have mainly aimed to prevent the illegal operations of using scrapped automobile parts to assemble vehicles, and sell them in the market to make profit out of it.
Actually, the ELV sector has put on a new image since 2019, when the Measures for Administration of Recycling of End-oflife Vehicles was revised. Before 2019, it was required that the "five assemblies" of ELVs must be destroyed and cannot flow, in any form, back into the market (State Council of China, 2000). Fortunately, with the upgrading of China's automobile industry, the occurrence of assembled automobiles is less frequently seen, while the tremendous waste of ELV resources has turned out to be the leading issue restricting the development of the industry. Taking 2019 as an example, only 1.951 million ELVs had been collected by qualified entities in China, while the de-registration data showed that the estimated number should be 5.8 million units. According to automobile sales and ownership changes, only about $30 \%$ of the ELVs flowed into the qualified dismantlers. As a result, there was enormous waste and loss of ELVs, which led to potential risks and environmental pollutions.

To deal with the issues in the ELVs recycling sector in 2019, the State Council passed the newly revised Measures for Administration of Recycling of End-of-life Vehicles, which have made adjustment of the following aspects targeting the incompatibility between the management system and the industry's needs (State Council of China, 2019):

1) Selling "five assemblies" of ELVs has been permitted to remanufacturing enterprises to improve resources recycling rate. After the adjustment, "five assemblies" could flow 
into formally established remanufacturers and re-entered the market as remanufactured products, which has greatly improved the recycling rate of automobile resources.

2) The number of ELV collecting and dismantling enterprises has no longer been under control to further facilitate free competition in the market. Before the adjustment, it had been required that each region should only, in principle, set up one entity for the collection of ELVs. The policy actually limited the numbers of recycling firms in the sector, which fostered monopoly at local levels, and hampered free competition. Fortunately, after the adjustment, the qualification certifying system has been further improved and unified planning removed, which has provided strong impetus to the market.

3) ELVs have no longer been collected at the prices of scrap metals, while traded at the price of useful parts. Before the adjustment, each automobile could cost but RMB 1,000, which had been greatly lower than the owners' expectation, leading to the outflow of some automobiles to illegal markets. After the adjustment, however, the ELVs have been traded at the market prices, leading ELVs to flow into qualified enterprises.

\section{Japan}

In Japan, over the years since the enactment of End-of-Life Vehicle Recycling Act (MOEJ) in 2005, the ELVs recycling system has evolved into a new stage under the government regulations and market requirement (Figure 11). When compared with what it was at the beginning of the policy design, the system has mainly seen the following changes:

1) ELV dismantling enterprises have gradually turned into the mainstream in the recycling system. In the original policy design, ELV collectors shall deliver the automobiles to fluorocarbons collectors, and then to dismantlers. However, due to high costs of transportation and under the impetus of foreseeable benefits out of ELVs dismantling, some dismantlers have more than been willing to undertake the work of ELV collecting, fluorocarbons collecting, automobile dismantling, and part of ELV residues' disposal. According to the statistical data released by JARC of Japan (2010-2019) (Automotive Recycling Data Report, 2019), the proportion of ELVs directly collected by dismantling/shredding enterprises increased from 70.7 to $86.9 \%$. The proportion of ELVs collected by enterprises with only collecting business decreased from 18.4 to $8.5 \%$ (Figure 12). This trend shows that ELVs dismantling enterprises have played an important role in the recycling system.

2) The role of ELVs recycling fee has gradually diminished. According to the law, recycling fees has been designed to facilitate the recycling. On the one hand, it could pay for the disposal of fluorocarbons, airbag and ASR; on the other hand, it could motivate automobile owners to deliver their cars to collectors (2004). However, as the marketization of the sector has furthered, enterprises have competed for ELVs resources. Against such a backdrop, when handing over their vehicles, the consumers not only could recover the recycling fees they have paid, but also could gain extra money, which is paid by the recycling companies basing on those vehicles' condition, and most often much more than the fees. As a result, the role of guidance of the policy of taking the recycling fees has been weakened.

The ELV recycling management in Japan oversees three aspects: ELVs, information, and capital, which involves multiple entities from enterprises, owners to the government. The integration of various factors has built a well-rounded ELV recycling system. However, when it is viewed from the industry's development over the years, even though the recycling system has been sophistically designed, the original intention has not been strictly followed, a new development model has evolved since then. Judging from its evolutionary path, it could be seen that market orientations have been the main driver of changes. Under the leverage of economic factors such as variable costs and ELVs' values, the sector shall move toward value maximization. Naturally, dismantlers have intended to handle the collection of ELVs and fluorocarbons. Meanwhile, the entities' competitiveness could be kept by raising purchase prices.

\section{Social Awareness of Resource Recycling}

Domestically, in addition to the support from government policies and the evolvement of the industry, a healthy development of the ELV recycling industry shall also rely on its integration with social awareness.

First and foremost, it requires an emphasis on recycling. China has been a large country with abundant natural resources, which has taken root in people's heart. Exploiting natural resources comes first, while the concept of recycling has been introduced quite lately and is not well-accepted. Consequently, for automobiles, the entire society's attention has been paid on production and consumption. However, recycling, the follow-up process in the industrial chain, has been neglected. In contrast, Japan is an island country with a size similar to that of Yunnan Province in China. It has been short of natural resources, especially landfill capacity, and relied on imports to maintain economic development. Therefore, Japan has attached great importance to the development, utilization and conservation of resources, and embarked much earlier on the path of circular economy. Since the beginning of the twenty-first century, Japan has achieved the transformation from a resource poor country to a powerful country through the development of circular society. It was against such a backdrop that Japan enacted the Waste Disposal Law (1970), the Resource Recycling Promotion Law (1991), and the Basic Law for Establishing the Recyclingbased Society (2000), etc., which created a reliable legal system. Meanwhile, economic leverages have been widely adopted to guide the operations of enterprises and behaviors of citizens. For instance, consumers have been required to pay recycling fees when they buy new cars, so as to enhance their awareness of resource recycling.

Secondly, it concerns social awareness of the social attributes of automobiles. Automotive products differ from products such as appliances and clothes. Apart from a strong dependence on energy and space, they, with prominent social attributes, involve social issues such as traffic safety and environmental protection. Before the revision of the Measures for Administration of Recycling of End-of-life Vehicles (State Council of China, 2000), the price of collecting of ELVs had been associated with scrap 


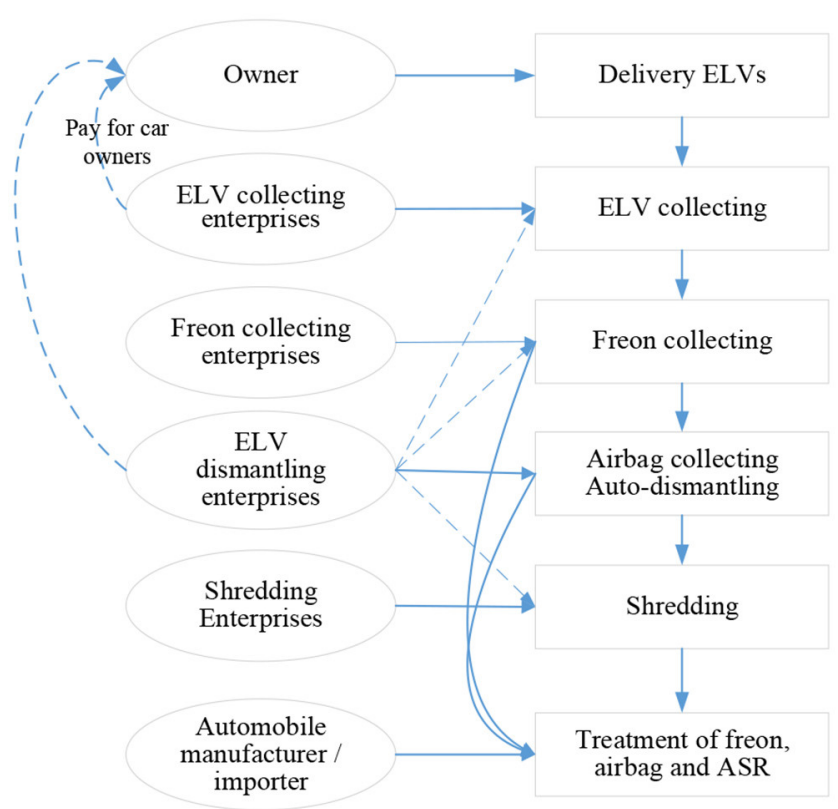

Initial system based on policy design

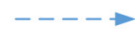

Current system evolved by practice

FIGURE 11 | Evolution of Japan's ELV recycling management framework.

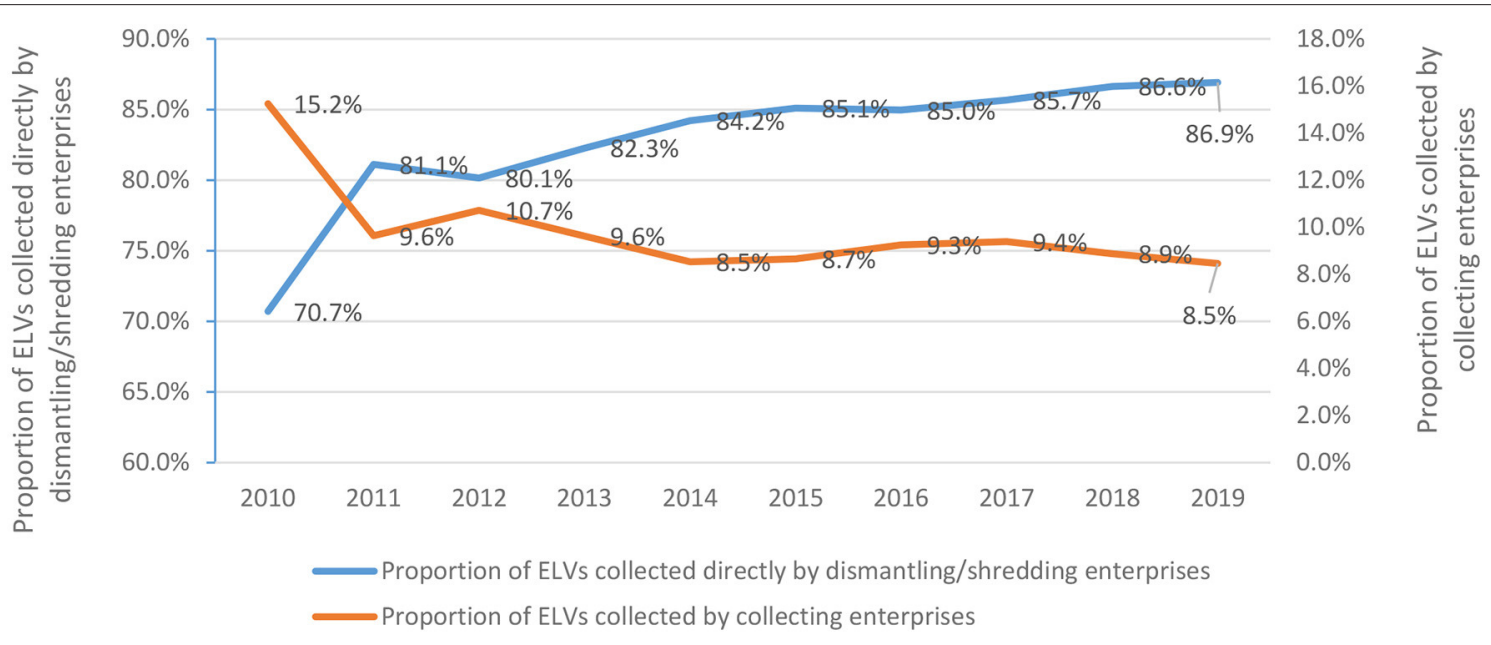

FIGURE 12 | The trend of proportion of ELVs being collected by various types of enterprises.

metals, which was far below the vehicle owners' expectation. Hence, unexpected amount of ELVs flew into the illegal market.

Due to weak awareness of the social attributes of automotive products, and the lackluster market push, numerous automobiles have not been well-handled, creating potential social dangers. In contrast, when it comes to Japan, on one hand, under the social influence of the recycling system, vehicle owners have recognized the social attributes of automotive products; on the other hand, thanks to the competition in the recycling market and the prevalence of circulation of used cars and ELVs, automobile owners could easily obtain appreciable value, and naturally are more willing to hand their ELVs over.
Compared with China, Japan has enjoyed the advantage of well-accepted social consensus in automobile recycling, which has been one of the drivers behind the normal operation of Japan's automobile recycling system. However, Japan's emphasis on environmental protection and resource utilization has begun in the 1970s, which has not gone through a long history. Back then, industrial pollution and resource consumption behind the rapid economic growth made Japanese realize the necessity of making a difference. Therefore, the social awareness of a country has been in constant evolution, which has been propelled, first and foremost, by the development of productivity. Actually, the transformation of social awareness takes the efforts of one generation or even several generations. 


\section{DISCUSSION}

\section{The Management Policies of Automobile Recycling Should Be Forward-Looking}

First of all, the impact shall be taken into consideration of the development trend of the production, the consumption, the second-hand vehicles, the maintenance, and other front-end segments in the automobile recycling industry in combination with the industrial environment of the domestic automobile market. Secondly, there shall be a sound prediction of the global market size and technological trends in advance, and prejudgment of the future development of the industry. Taking the rise of new energy vehicles as an example, about 40 countries cross the glove have realized a large-scale promotion and application of the technology. In 2019, the global sales volume of new energy vehicles exceeded 2.1 million sets, and the ownership reached 7.2 million sets. It is estimated that by 2030 , the sales volume of new energy vehicles will reach 43 million sets, and the ownership will exceed 250 million sets (2020). The high rocketing ownership of new energy vehicles has posted new requirement for energy input, resource utilization, and environmental protection.

In addition, the reasonability and feasibility shall be fully assessed of the combination of the industry's management with regulatory tools such as taxes, financial tools, insurances, funds among others. At present, many Asian countries are in the process of development, and most of their automobile industries are either at the start-up or development stage. With the outburst of vehicle ownership, they shall face many challenges problems in the future, such as vehicle recycling and scrapping, material reuse, electric vehicle scrapping, etc. Therefore, it is of great importance to implement forward-looking mindset in the making of automobile recycling policies (Chen and Zhang, 2009; D’Adamo et al., 2020).

\section{An Organic Integration With the Market Is a Key Driver for the Stable Operation of the System}

It could be learned from the industrial development of the world, China and Japan that no matter what kind of models they have adopted, they shall sooner or later move toward a market-driven and value-driven model with the development upgrading of the industry (Forton et al., 2006; Vermeulen et al., 2011). As a result, a complete integration with the market is necessary for a rapid and healthy development of the industry. It turns out that even an ELV could maximize surplus-value. Under the market model, the smoothest development path is bound to be the one that could maximize surplus-values. For instance, Japanese companies pay automobile owners far more sums than recycling fees to improve their competitiveness. However, in China, due to the low revenue of ELVs recycling, most ELVs have not been well-recycled. As result of market changes, "five assemblies" have changed from being destroyed to being remanufactured.

\section{An Improved EPR System Should Be Established}

In the processes of the design, manufacturing, marketing, and recycling of automobiles, the manufacturers are involved in most of the industrial chain. They possess obvious advantages in technologies, recycling, and collecting networks, and could play a vital role. It is essential to draw lessons from Japan's experience and good global practices to formulate the Extended Producer Responsibility (EPR) system, and establish a producerled recycling system (Wang et al., 2017). For Asian countries, especially, the EPR concept has not been well-received yet. Basic obligations such as the publication of automobile dismantling manuals and the establishment of a recycling network have yet to be performed.

\section{The Establishment of Social Awareness of Resource Recycling Should Integrate With the Actual Situation of the Country and Be Implemented Gradually}

Automobile products features a long industrial supply chain and covers wide aspects. A number of participants involve in the recycling end of the chain, including vehicle manufactures, insurance agencies, used parts circulation companies, ELVs collectors, dismantlers and recyclers, steel makers, waste disposal enterprises, shredders, consumers, etc. (Sakai et al., 2020). Therefore, it takes the joint efforts of all participants to build an effective recycling system. Against such a background, an effective integration of the processes in the system with a strong awareness of resource recycling are necessary for its sound operation. The existing automobile recycling system in Japan, for instance, has relied on a relatively established social awareness to run smoothly (Tanaka, 1999). Yet it has built on a legal design embracing recycling fees, active sale of ELVs, wide circulation of used cars and parts, and refinement of dismantling work, which also has continuously adopted external advanced experience for reference (Ueta and Koizumi, 2001).

\section{Explore the Sustainable Recycling System Under the Background of Global Integration}

Nowadays, the automobile industry has achieved a high degree of globalization, and the recycling industry at the end of the industrial chain shall inevitably join the trend of global integration. Judging from the development of China and Japan, it can be seen that whether it is the rise of electric vehicles worldwide, or the global circulation of used cars and parts, or the global extension of EPR, the automobile recycling industry shall be impacted (Steward and Mayyas, 2019; Li et al., 2020). Therefore, it is necessary to reflect on such aspects as related policies' formulation, the sector's management, technologies' upgrading, and the circulation of products in line with the development of the global industry. Meanwhile, an adaptive recycling systems to the future development trend shall be explored continuously.

\section{CONCLUSION}

In this paper, the Material Flow Analysis (MFA) method is adopted to analyses the input and output of China's automobile industry, the Resource Input Intensity (RII) of steel and oil, as well as the recycling of ELVs in Japan. Thanks to the lightweight 
trend, the consumption of steel has decreased over the years. However, in terms of the material recycling rate, Japan registered 99\%, 9 percentage points higher than that of China. With the improvement of recycling technologies and the enacting of relevant facilitating policies, the number in China is expected to reach $98 \%$ in 2025 . Fortunately, the new trend not only affects China, but also impacts Asia and even the world at large. It shall continue to bring about changes in the proportion of compositions of automobile materials in the future, thus affecting the recycling of those materials and waste disposal. What's more, it also provides a reference for future direction of material recycling and the enactment of forward-looking management policy about automobile recycling.

This paper adopts, for the first time, the social awareness of resource recycling as one of the key factors influencing the development of ELV recycling industry, and analyzes into various development stages of it on the industry. From the analysis of social awareness between China and Japan, it can be seen that the social attributes of ELV recycling industry are very strong, especially in developing countries, where the awareness is still being shaped. Therefore, to improve the industry, not only shall we maneuver within the industry, but also require the joint efforts from the entire society.

In addition to learning from Japan's recycling system, this paper also studies the deviation between Japan's current system and its original policy designs, where the possible causes are analyzed. It concludes that there always is and will be deviation between the guidance framework of policies or regulations, and the actual development of the regulated industry. As for the main cause herein, it is market evolvement. The maximization of remained value of ELVs has been the ultimate goal of the industry. As for how to integrate the two organically on the prerequisite of safety and environmental protection, it is the challenge facing the administrative bodies. For Asian countries, especially, while they are at an immature stage of industrial development, more attention should be paid to the guiding role of the market.

As for China, Japan, and other Asian countries, in the face of new recycling system, and ever-changing technical

\section{REFERENCES}

Aki, H. (2016). The Current Situation of Japan's Automobile Recycling System. Tokyo: Japan's Ministry of Economy, Trade and Industry.

Ardente, F., Talens Peiró, L., Mathieux, F., and Polverini, D. (2018). Accounting for the environmental benefits of remanufactured products: method and application. Clean. Product. 198, 1545-1558. doi: 10.1016/j.jclepro.2018. 07.012

Automotive Recycling Data Report (2019). Automotive Recycling Data Report. Tokyo: Japan Automobile Recycling Promotion Center.

Bao, C. M. (2011). Material Flow Analysis of Automobile Industry in China. Tianjin: Tianjin University.

Bobba, S., Tecchio, P., Ardente, F., Mathieux, F., dos Santos, F. M., and Pekar, F. (2020). Analysing the contribution of automotive remanufacturing to the circularity of materials. 27th CIRP Life Cycle Engineering (LCE) Conference. Proc. CIRP 90, 67-72. doi: 10.1016/j.procir.2020.02.052

Business Office of the Chinese Embassy in Japan (2005). Management System of Scrapped Vehicles in Japan. Ministry of Commerce.

Che, J., Yu, J., and Kevin, R. S. (2011). End-of-life vehicle recycling and international cooperation between Japan, China and Korea: requirements, policies, market orientation, social awareness of resource recycling, and sustainable development, they shall be all taken into consideration to deal with the impact on the future development and explore the right path for domestic industries while coping with new overseas demands from the automobile industry.

\section{DATA AVAILABILITY STATEMENT}

The original contributions generated for the study are included in the article/supplementary material, further inquiries can be directed to the corresponding author/s.

\section{AUTHOR CONTRIBUTIONS}

JW: data curation, writing-original draft, writing-review, and editing. LS: methodology, writing — original draft, writingreview, and editing. MF, YL, SM, and ID: resources, writingreview, and editing. YH: resources and supervision. WP and ZL: data curation. All authors contributed to the article and approved the submitted version.

\section{FUNDING}

This manuscript was supported by the National Key R\&D Program of China (No. 2018YFC1902704); National Science Foundation, China, NSFC (NSFC-NWO project, No. 72061137071) and NWO project on Toward Inclusive Circular Economy: Transnational Network for Wise-waste Cities (IWWCs) (No. 482.19.608); Environment Research and Technology Development Fund (JPMEERF20193005) of the Environmental Restoration and Conservation Agency of Japan.

\section{ACKNOWLEDGMENTS}

We acknowledge the data and valuable suggestions from Dr. Tomohiro Tasaki, National Institute for Environmental Studies, Japan. present and future scenario analysis. Environ. Sci. 23, 162-166. doi: 10.1016/S1001-0742(11)61103-0

Chen, M. (2016). Technology Roadmap of China's Automobile Product Recycling Industry. Shanghai: Strategic Alliance for Technological Innovation of Automobile Product Recycling Industry.

Chen, M., and Zhang, F. (2009). End-of-Life vehicle recovery in china: consideration and innovation following the EU ELV directive. JOM 61, 45-52. doi: 10.1007/s11837-009-0040-8

China Material Recycling Association (2020). Development Report on Recycling and Dismantling of End-of-Life Motor Vehicles in China Report. Beijing: China Material Recycling Association.

D’Adamo, I., Gastaldi, M., and Rosa, P. (2020). Recycling of end-of-life vehicles: assessing trends and performances in Europe. Technol. Forecast. Soc. Change 152:119887. doi: 10.1016/j.techfore.2019.119887

Daisaku, H., Hiteki, M., and Tomohiro, T. (2003). "Investigation on the actual process of reusing and disposing scrapped vehicles," in Proceedings of the 14th Research Conference of Waste Society, (Tokyo) 153-155.

Daniels, E. J., Carpenter, J. A., and Duranceau, C. (2004). Sustainable end-of-life vehicle recycling: R\&D collaboration between industry and the U.S. JOM 56, 28-32. doi: 10.1007/s11837-004-0177-4 
Ellen MacArthur Foundation (2013). The Circular Economy Applied to the Automotive Industry. Available online at: https://www. ellenmacarthurfoundation.org/news/the-circular-economy-applied-tothe-automotive-industry (accessed December, 2019).

EUROSTAT (1997). Materials Flow Accounting: Experience of Statistical Offices in Europe, Directorate B: Economic Statistics and Economic and Monetary Convergence, Luxembourg.

EUROSTAT (2001). Economy-wide Material Flow Account and Derived Indicators: A Methodological Guide, Luxembourg: Office for Official Publications of the European Communities.

Forton, O. T., Harder, M. K., and Moles, N. R. (2006). Value from shredder waste: ongoing limitations in the UK. Resour. Conservat. Recycling 46, 104-113. doi: 10.1016/j.resconrec.2005.06.007

Hu, G. Y., Du, Z. P., and Zhou, S. Y. (2009). Comparative study on automobile recycling and dismantling between China and Japan. Int. Log. 28, 251-262. doi: 10.3969/j.issn.1005-152X.2009.07.081

International Energy Agency (2020). Global EV Outlook Report. Paris: International Energy Agency (IEA).

International Reference Life Cycle Data System (2010). International Reference Life Cycle Data System (ILCD) Handbook: Framework and Requirements for Life Cycle Impact Assessment Models and Indicators. JRC-IES. Luxembourg: European Commission.

Japan's Ministry of Economy, Trade and Industry (2005). Japan's ELVs Recycling Management Framework.

Jody, B. J., and Daniels, E. J. (2011). End-of-Life Vehicle Recycling: State of the Art of Resource Recovery from Shredder Residue. Argonne, IL: Argonne National Lab (ANL). doi: 10.2172/1010492

Kanari, N., Pineau, J., and Shallari, S. (2003). End-of-life vehicle recycling in the European union. JOM 55, 15-19. doi: 10.1007/s11837-003-0098-7

Kenta Sato, F. E., Furubayashi, T., and Nakata, T. (2019). Application of energy and $\mathrm{CO}_{2}$ reduction assessments for end-of-life vehicles recycling in Japan. Appl. Energy 237. 779-794. doi: 10.1016/j.apenergy.2019.01.002

Li, J., Zhi, Q., and Simeonec, A. (2020). An activity theory-based analysis approach for end-of-life management of electric vehicle batteries. Resour. Conservat. Recycling 162:105040. doi: 10.1016/j.resconrec.2020.105040

Li, J. H., Yu, K. L., and Gao, P. (2014). Recycling and pollution control of the End of Life Vehicles in China. Mater Cycles Waste Manag. 16, 31-38. doi: 10.1007/s10163-013-0226-6

Li, W. B., Bai, H. T., and Yin, J. F. (2016). Life cycle assessment of end-of-life vehicle recycling processes in China-take Corolla taxis for example. Clean. Product. 117, 176-187. doi: 10.1016/j.jclepro.2016.01.025

Li, Y., Fujikawa, K., and Wang, J. B. (2020). The potential and trend of end-of-life passenger vehicles recycling in China. Sustainability 12:1455. doi: $10.3390 /$ sul2041455

Liu, M. Z., Chen, X. H., and Zhang, M. Y. (2020). End-of-life passenger vehicles recycling decision system in China based on dynamic material flow analysis and life cycle assessment. Waste Manag. 117, 81-92. doi: 10.1016/j.wasman.2020.08.002

Ministry of Economy, Trade and Industry of Japan (2002). Ministry of economy, trade and industry of Japan. End-of-Life Vehicle Recycling Act (MOEJ).

Ministry of Economy, Trade and Industry of Japan, and Ministry of Environment of Japan (2004). National Explanatory Report of End-of-Life Vehicle Recycling Act (MOEJ). Tokyo: Ministry of Economy, Trade and Industry of Japan, Ministry of Environment of Japan.

National Development and Reform Commission of China (2006). Technical Policy on Automobile Product Recycling.

Ni, F. J. (2015). Preliminary Study on the Mechanism of Pyrolysis Gasification Recovery and Resource Utilization of Scrap Vehicle Debris. Shanghai: Shanghai Jiaotong University.

Ogushi, Y., and Kandlika, M. (2005). "The impact of end-of-life vehicle recycling law on automobile recovery in Japan," in 2005 4th International Symposium on Environmentally Conscious Design and Inverse Manufacturing (Tokyo), 626-633.

Pan, Y. X., and Li, H. T. (2016). Sustainability evaluation of end-of-life vehicle recycling based on energy analysis: a case study of an end-of-life vehicle recycling enterprise in China. Clean. Product. 131, 219-227. doi: $10.1016 /$ j.jclepro.2016.05.045
Sakai, S., Yoshida, H., and Hiratsuka, J. (2020). An international comparative study of end-of-life vehicle (ELV) recycling systems recycling systems. Waste Manag. 117, 81-92. doi: 10.1007/s10163-013-0173-2

Sakai, S. I., Noma, Y., and Kida, A. (2007). End-of-life vehicle recycling and automobile shredder residue management in Japan. Mater Cycles Waste Manag. 9, 151-158. doi: 10.1007/s10163-007-0180-2

Shen, J. (2013). Discussion on calculation of automobile recyclability and recyclability. Shanghai Automot. 6, 53-56. doi: 10.3969/j.issn.1007-4554.2013.06.14

Soo, V. K., Doolan, M., Compstona, P., Duflou, J. R., Peeters, J., and Umeda, Y. (2021). The influence of end-of-life regulation on vehicle material circularity: a comparison of Europe, Japan, Australia and the US. Resour. Conserv. Recycling 168:105294. doi: 10.1016/j.resconrec.2020.105294

State Council of China (2000). Measures for Administration of Recycling of End-oflife Vehicles.

State Council of China (2019). Measures for Administration of Recycling of End-oflife Vehicles.

Steward, D., Mayyas, A. and Mann, M. (2019). Economics and challenges of li-ion battery recycling from end-of-life vehicles. Econ. Challenge. $\mathrm{Li}$ Ion Battery Recycling End Sci. Direct 4:33. doi: 10.1016/j.promfg.2019. 04.033

Tanaka, M. (1999). Recent trends in recycling activities and waste management in Japan. Mater Cycles Waste Manag. 1, 10-16.

The National People's Congress of China (2008). Circular Economy Promotion Law of the People's Republic of China.

Tomohiro, T., Atsushi, T., and Yuichi, M. (2004). "The actual situation and national calculation of auto parts and materials recycling," in Proceedings of the 15th Research Conference of Waste Society, (Tokyo) 245-224.

Ueta, K., and Koizumi, H. (2001). Reducing household waste: Japan learns from Germany. Environ. Sci. Policy Sustain. Dev. 43, 20-32. doi: $10.1080 / 00139150109604512$

Vermeulen, I., Van Caneghem, J., and Block, C. (2011). Automotive shredder residue (ASR): reviewing its production from end-of-life vehicles (ELVs) and its recycling. Energy Chem. Valorizat. 190, 8-27. doi: 10.1016/j.jhazmat.2011.02.088

Wang, J., Li, Y. K., and Pan, W. (2015). Analysis on policy environment of China's ELVs recycling industry. Automot. Industr. Res. 12, 34-36. doi: 10.3969/j.issn.1009-847X.2015.12.007

Wang, L., and Chen, M. (2013). Policies and perspective on end-of-life vehicles in China. Clean. Product. 44, 168-176. doi: 10.1016/j.jclepro.2012. 11.036

Wang, S. Y., Fan, G. Y., and Yu, J. S. (2017). "The trace and features of EPR in ELVs recycling system: comparison of international trend," in Proceedings of the 28th Annual Conference of Japan Society of Material Cycles and Waste Management, (Tokyo) 543-544.

Wang, X., and Chen, M. (2011). Implementing extended producer responsibility: vehicle remanufacturing in China. Clean. Product. 19, 680-686. doi: 10.1016/j.jclepro.2010.11.016

Zhao, Q. H., and Chen, M. (2019). A comparison of ELVs recycling system in China and Japan and China's strategies. Resour. Conservat. Recycling 237, 779-794. doi: 10.1016/j.resconrec.2011.09.010

Zhou, F., Lim, M. K., He, Y., Lin, Y., and Chen, S. (2019). End-of-life vehicle (ELV) recycling management: Improving performance using an ISM approach. Clean. Product. 228, 231-243. doi: 10.1016/j.jclepro.2019. 04.182

Conflict of Interest: The authors declare that the research was conducted in the absence of any commercial or financial relationships that could be construed as a potential conflict of interest.

Copyright (๑ 2021 Wang, Sun, Fujii, Li, Huang, Murakami, Daigo, Pan and Li. This is an open-access article distributed under the terms of the Creative Commons Attribution License (CC BY). The use, distribution or reproduction in other forums is permitted, provided the original author(s) and the copyright owner(s) are credited and that the original publication in this journal is cited, in accordance with accepted academic practice. No use, distribution or reproduction is permitted which does not comply with these terms. 